\title{
PENGEMBANGAN SISTEM INFORMASI MANAJEMEN PELAYANAN PELAPORAN SAPU BERSIH PUNGUTAN LIAR PADA KEMENKOPOLHUKAM JAKARTA
}

\author{
Ependi $^{1}$ \\ ${ }^{1}$ Program Studi Manajemen \\ Universitas Mohammad Husni Thamrin \\ ependi71@yahoo.com
}

\author{
Fadhlan Muharom ${ }^{2}$ \\ ${ }^{2}$ Program Studi Teknik Informatika \\ Universitas Mohammad Husni Thamrin \\ fadhlanmuharom@gmail.com
}

\begin{abstract}
As there are many cases of illegal collection that occur in the community, it is necessary to improve services carried out by the Task Force to Clean Illegal Levies at the Kemenkopolhukam, especially in the Jakarta area. To improve services to the community, an information processing system for data reports on illegal fees is required. So far, the report management system used is still manual, namely the public or the reporters come to the Saber Pungli Task Force office, then the officer will process the report data.

Design of Management Information Systems Reporting Services Application was developed with systems development models such as Undified Modeling Language (UML), Entity Relationship Diagram (ERD), Normalization to Input and Output Design.

With a management Information System, accurate and relevant computer-based reporting services, it can solve problems related to the illegal levy sweep reporting process. After the entire system has been created, it can be seen that the new Reporting Service Application Management information system design can produce fast, accurate and relevant information.
\end{abstract}

Keywords: Management Information Systems, Reporting Services, Illegal Levies

Abstrak- Seiring banyaknya kasus pemungutan liar yang terjadi di masyarakat, maka diperlukan peningkatan pelayanan yang dilakukan oleh Satuan Tugas Sapu Bersih Pungutan Liar pada Kemenkopolhukam, khususnya di wilayah Jakarta. Untuk meningkatkan pelayanan kepada masyarakat, maka diperlukan sistem pengolahan informasi data laporan pungutan liar. Sejauh ini sistem pengelolaan laporan yang digunakan masih secara manual, yakni masyarakat atau pelapor datang ke kantor Satgas Saber Pungli, lalu petugas yang akan mengolah data laporan tersebut.

Perancangan Sistem Informasi Manajemen Aplikasi Pelayanan Pelaporan dikembangkan dengan model-model pengembangan sistem seperti Undified Modelling Language (UML), Entity Relationship
Diagram (ERD), Normalisasi hingga Desain Input dan Output.

Dengan suatu rancangan Sistem Informasi Manajemen pelayanan pelaporan berbasis komputer yang tepat, akurat dan relevan, dapat menyelesaikan masalah yang berhubungan dengan proses pelaporan sapu bersih pungutan liar. Setelah keseluruhan sistem selesai dibuat, dapat diketahui bahwa dengan rancangan sistem informasi Manajemen Aplikasi Pelayanan Pelaporan yang baru dapat menghasilkan informasi yang cepat, akurat dan relevan.

Kata Kunci : Sistem Informasi Management, Pelayanan Pelaporan, Pungutan Liar

\section{PENDAHULUAN}

Dinamika teknologi sangat pesat dari waktu ke waktu. Seiring dengan kebutuhan akan informasi yang lebih baik dari segi kuantitas maupun kualitasnya, mengakibatkan kebutuhan akan sebuah sistem informasi yang dapat meningkatkan kinerja suatu instansi dan mempermudah pekerjaan menjadi prioritas yang utama. Sistem yang mampu mengolah data dalam jumlah yang sangat besar dengan tingkat kecepatan yang tinggi, tentunya dapat meningkatkan kemampuan sebuah instansi atau lembaga dalam efisiensi pengambilan sebuah keputusan.

Efektivitas dan kinerja suatu instansi dapat tercapai dengan maksimal, apabila perusahaan tersebut memiliki suatu sistem dengan manajemen yang baik, yang depat bekerja secara efisien, efektif dan ekonomis. Tanpa manajemen yang baik serta ditunjang oleh sistem dan pegawai

Jurnal Teknologi Informatika \& Komputer| Volume 3 No. 2, September 2017

http://journal.thamrin.ac.id/index.php/jtik/article/view/396/pdf 
yang berkualitas tinggi, sebuah instansi hanya akan mempunyai sedikit peluang untuk berkembang dan target instansi tersebut tidak mungkin tercapai.

Untuk itu, kebutuhan akan sistem adalah mutlak diperlukan guna meningkatkan efisiensi dan efektifitas kerja. Salah satunya adalah penggunaan komputer dalam memproses data. Dalam hal ini, selain dapat memproses semua data yang diperlukan oleh perusahaan, komputer juga dapat membuat laporan yang akan sangat membantu pemimpin instansi untuk mengambil keputusan yang penting bagi kemajuan dan perkembangan instansi tersebut.

Sistem Informasi Manajemen Pelayanan Pelaporan Sapu Bersih Pungutan Liar pada Kementerian Koordinator Politik Hukum dan Keamanan sampai saat ini masih dilakukan secara manual, sehingga sering mengakibatkan keterlambatan dalam memperoleh informasi yang dibutuhkan, terutama laporan pengaduan. Dibutuhkan penggunaan komputer sebagai alat bantu dalam mengolah data pelaporan Sapu Bersih Pungutan Liar pada Kementerian Koordinator Politik Hukum dan Keamanan.

Adapun maksud dan tujuan dari penelitian antara lain: Membuat Sistem Informasi Manajemen dimana terdapat Aplikasi pendataan laporan sebagai solusi untuk mengatasi masalah pendataan laporan pungutan liar di Kementerian Politik Hukum dan Keamanan. Meningkatkan kinerja instansi untuk dalam pelayanan terhadap masyarakat.

Dalam penelitian ini akan dikembangkan Sistem Informasi Manajemen Pendataan Pelaporan Sapu Bersih pungutan liar yang menangani surat menyurat dan pengaduan langsung. Sistem keamanan data berdasarkan user level yang dilakukan di Kementerian Politik Hukum dan Keamanan.

Pungutan liar adalah perbuatan yang dilakukan oleh seseorang atau Pegawai Negeri atau
Pejabat Negara dengan cara meminta pembayaran sejumlah uang yang tidak sesuai atau

tidak berdasarkan peraturan yang berkaitan dengan pembayaran tersebut. Hal ini sering disamakan dengan perbuatan pemerasan, penipuan atau korupsi.

Tingginya tingkat ketidakpastian pelayanan sebagai akibat adanya prosedur pelayanan yang panjang dan melelahkan menjadi penyebab semakin banyaknya masyarakat yang menyerah ketika berhadapan dengan pelayanan publik yang korup. Hal ini merupakan salah satu faktor yang menyebabkan masyarakat cenderung semakin toleran terhadap praktik pungutan liar dalam penyelenggaraan pelayanan publik.

Pungutan liar merupakan gejala sosial yang telah ada di Indonesia, sejak Indonesia masih dalam masa penjajahan dan bahkan jauh sebelum itu. Namun penamaan perbuatan itu sebagai perbuatan pungli, secara nasional baru diperkenalkan pada bulan September 1977, yaitu saat Kaskopkamtib yang bertindak selaku Kepala Operasi Tertib bersama Menpan dengan gencar melancarkan Operasi Tertib (OPSTIB), yang sasaran utamanya adalah pungli.

Pada masa Undang-Undang No. 3 Tahun 1971 tentang Pemberantasan Tindak Pidana Korupsi, dikeluarkan Instruksi Presiden No. 9 tahun 1977 tentang Operasi Penertiban (1977-1981), dengan tugas membersihkan pungutan liar, penertiban uang siluman, penertiban aparat pemda dan departemen. Untuk memperlancar dan mengefektifkan pelaksanaan penertiban ini ditugaskan kepada Menteri Negara Penertiban Aparatur Negara, untuk mengkoordinir pelaksanaannya dan Pangkopkamtib untuk membantu Departemen atau Lembaga pelaksanaanya secara operasional.

Pungutan liar juga termasuk dalam kategori kejahatan jabatan, di mana dalam konsep kejahatan jabatan di jabarkan bahwa pejabat demi menguntungkan diri sendiri atau orang lain, 
menyalahgunakan kekuasaannya untuk memaksa seseorang untuk memberikan sesuatu, untuk membayar atau menerima pembayaran dengan potongan, atau untuk mengerjakan sesuatu bagi dirinya sendiri.

Dalam rumusan korupsi pada Pasal 12 huruf e UU No. 20 Tahun 2001 berasal dari Pasal 423 KUHP yang dirujuk dalam Pasal 12 UU No.31 Tahun 1999 sebagai tindak pidana korupsi, yang kemudian dirumuskan ulang pada UU No.20 Tahun 2001 (Tindak Pidana Korupsi), menjelaskan definisi pungutan liar adalah suatu perbuatan yang dilakukan pegawai negeri atau penyelenggara yang dengan maksud menguntungkan diri sendiri atau orang lain secara melawan hukum, atau dengan menyalahgunakan kekuasaannya memaksa seseorang memberikan sesuatu, membayar, atau menerima pembayaran dengan potongan, atau untuk mengerjakan sesuatu bagi dirinya sendiri.

Istilah lain yang dipergunakan oleh masyarakat mengenai pungutan liar atau pungli adalah uang sogokan, uang pelicin, salam tempel dan lain lain. Pungutan liar pada hakekatnya adalah interaksi antara petugas dengan masyarakat yang didorong oleh berbagai kepentingan pribadi.

\section{METODE PENELITIAN}

Pada Sistem berjalan, pelapor datang ke posko dan langsung di terima oleh operator posko atau katim posko, memberikan barang bukti laporan dan memberikan keterangan laporan yang di terima oleh operator posko atau katim posko. Setelah itu pelapor akan di berikan bukti laporan bahwa sudah melapor ke posko SATGAS SABER PUNGLI dan bukti laporan akan di berikan kepada bagian yang bersangkutan. Apabila surat yang datang ke posko melalui pos maka surat akan di data nomor surat, tanggal datang surat dan nama/instansi pelapor pungutan liar, setelah itu surat akan didistribusikan kepada pihak yang berwajib atau berhak.
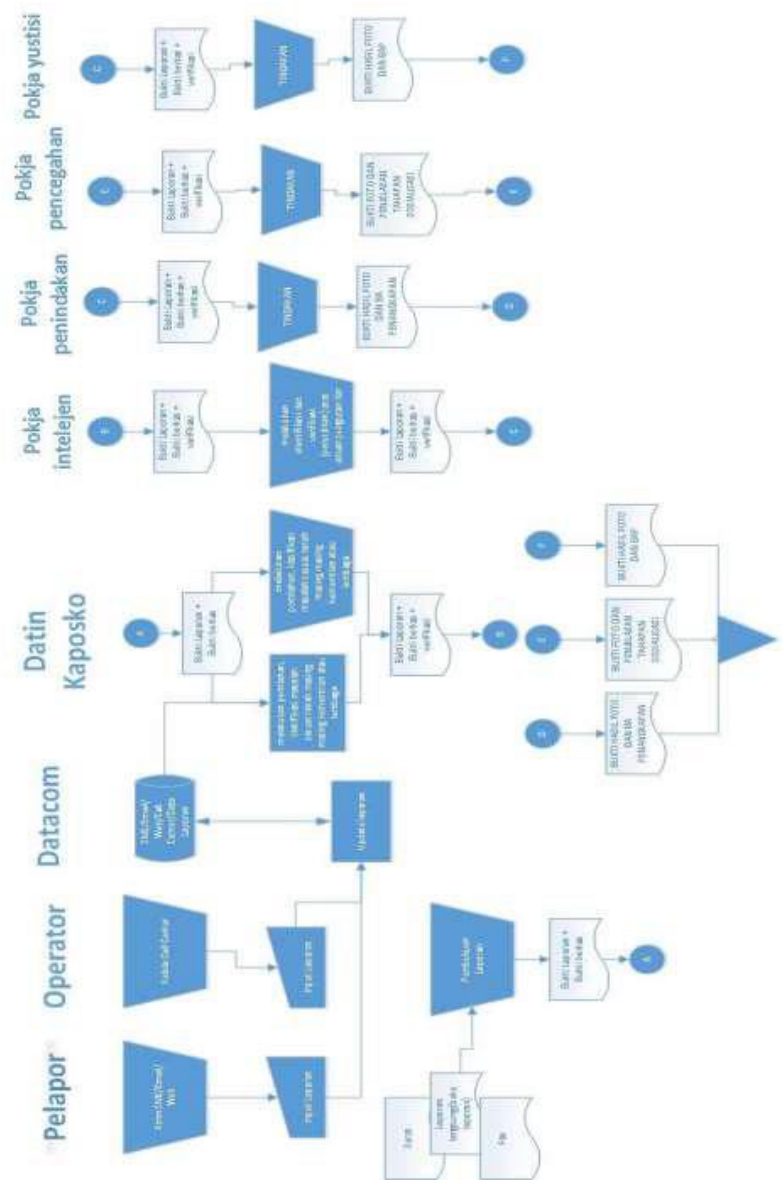

Gambar 1. Flowchart Sistem Berjalan 
Metode pengembangan sistem yang digunakan adalah metode waterfall dengan rincian proses sebagaimana di gambar 2.

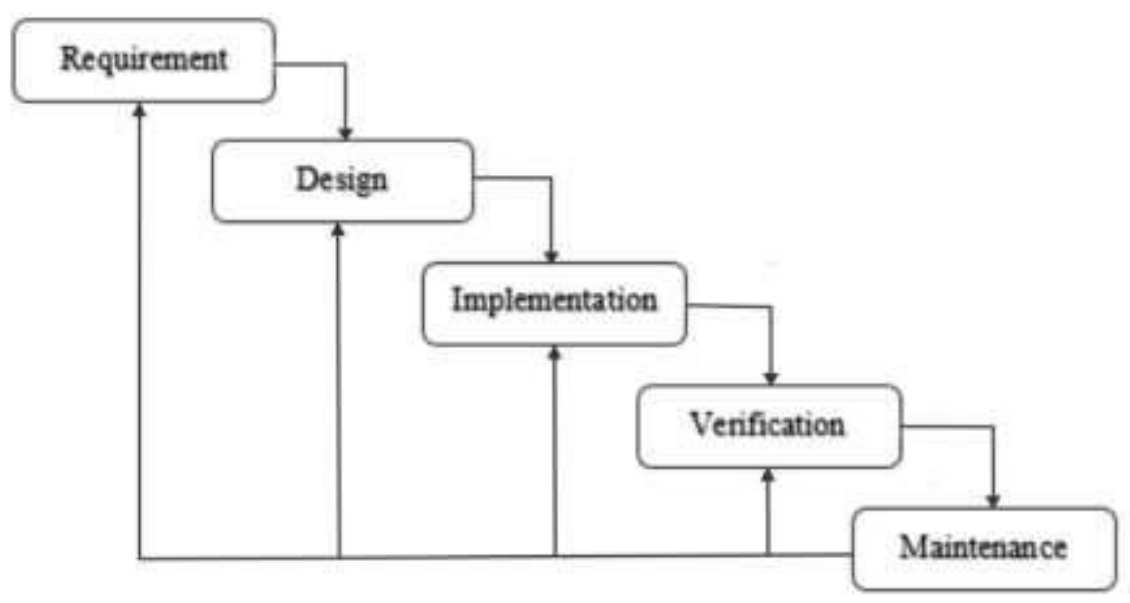

Gambar 2. Pengembangan Sistem Metode Waterfall

\section{HASIL DAN PEMBAHASAN}

Penelitian ini meliputi pembuatan Sistem Informasi Manajemen Pelaporan secara digital pada Satgas Saber Pungli di Kemenko Polhukam. Semua data laporan dan pengolahan data tersimpan ke database sehingga data tidak akan hilang dan memudahkan dalam setiap laporan. 


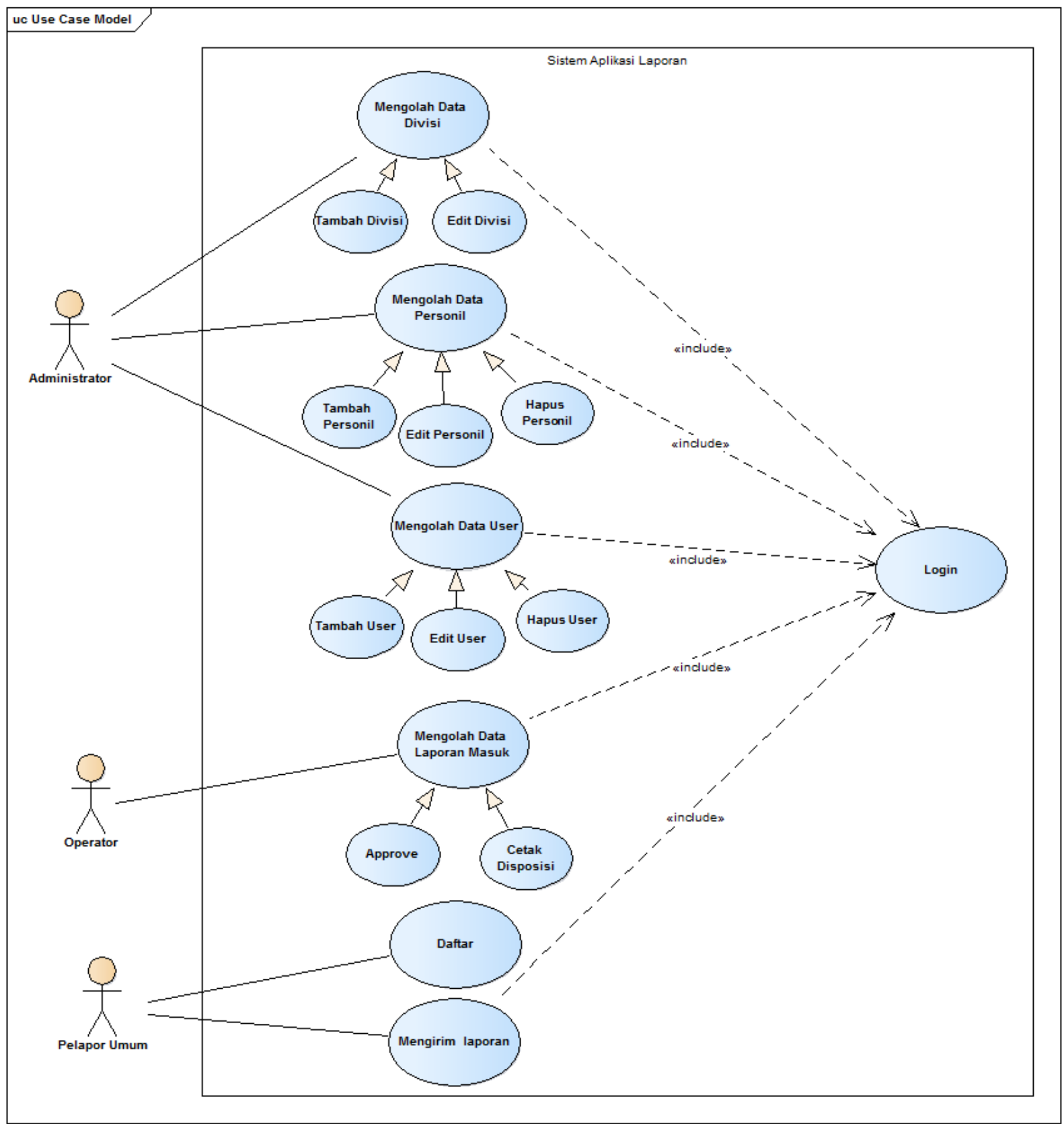

Gambar 3. Diagram Use Case 

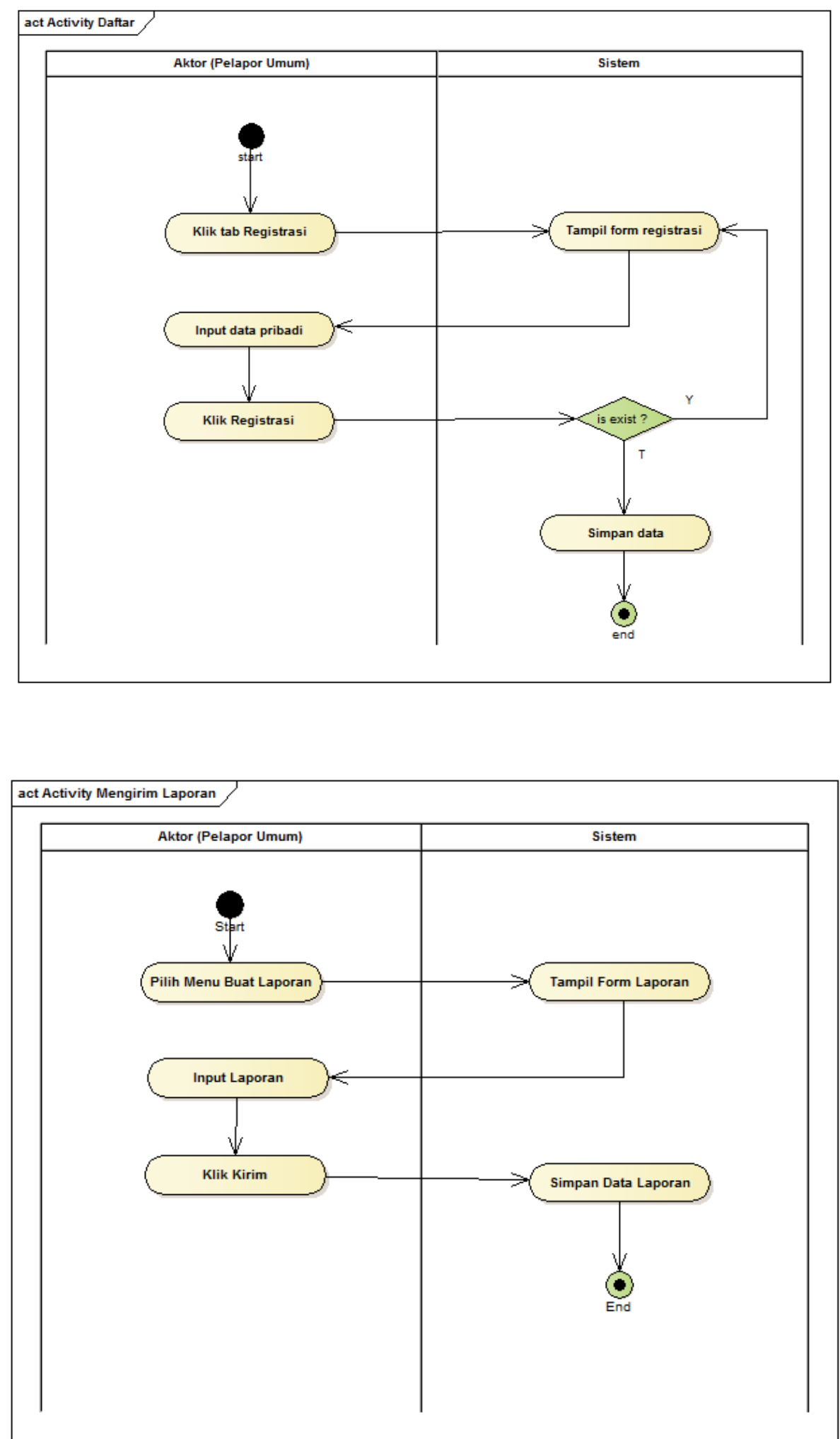

Gambar 4. Activity Diagram 


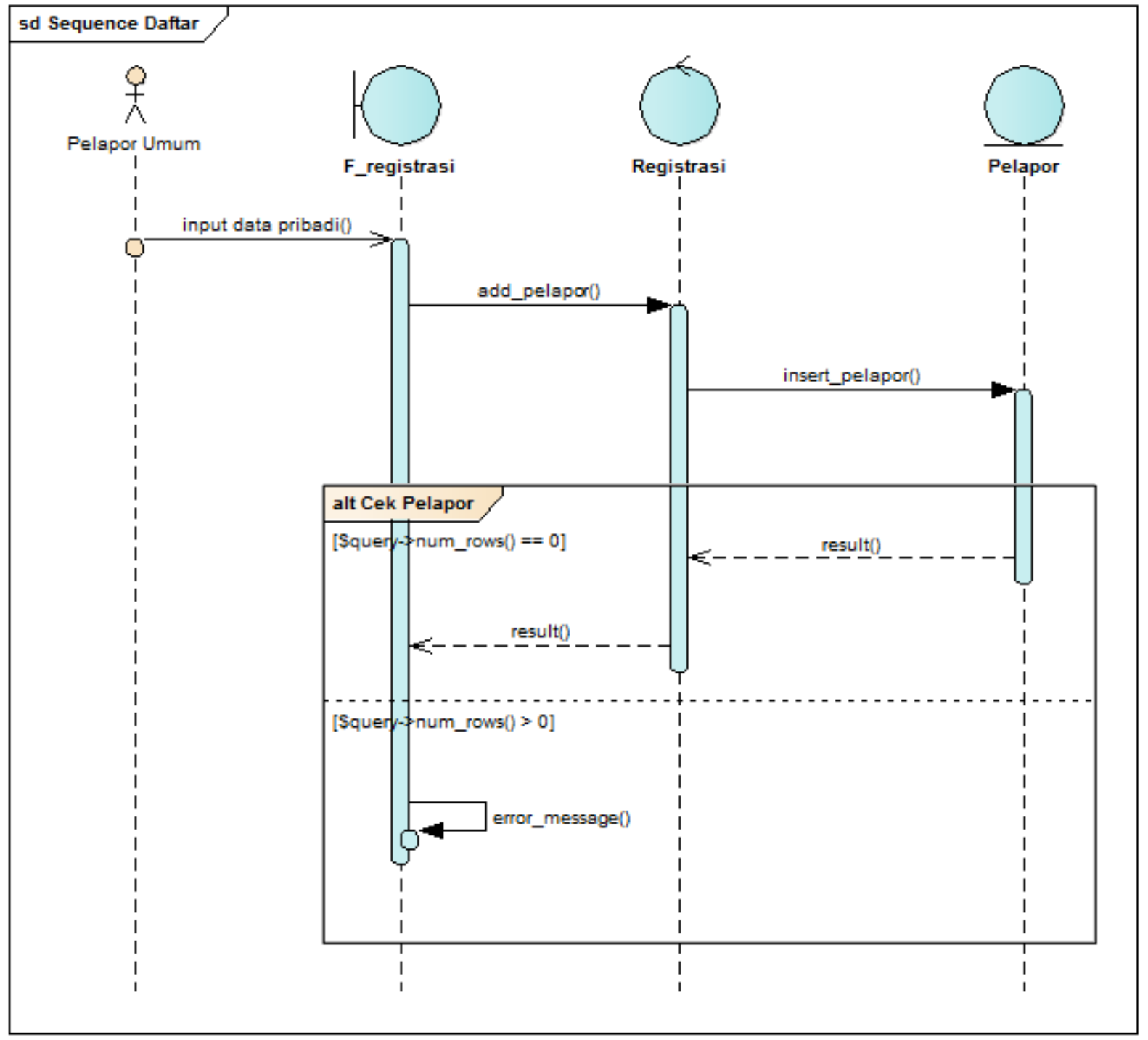

Gambar 5. Sequence Diagram 


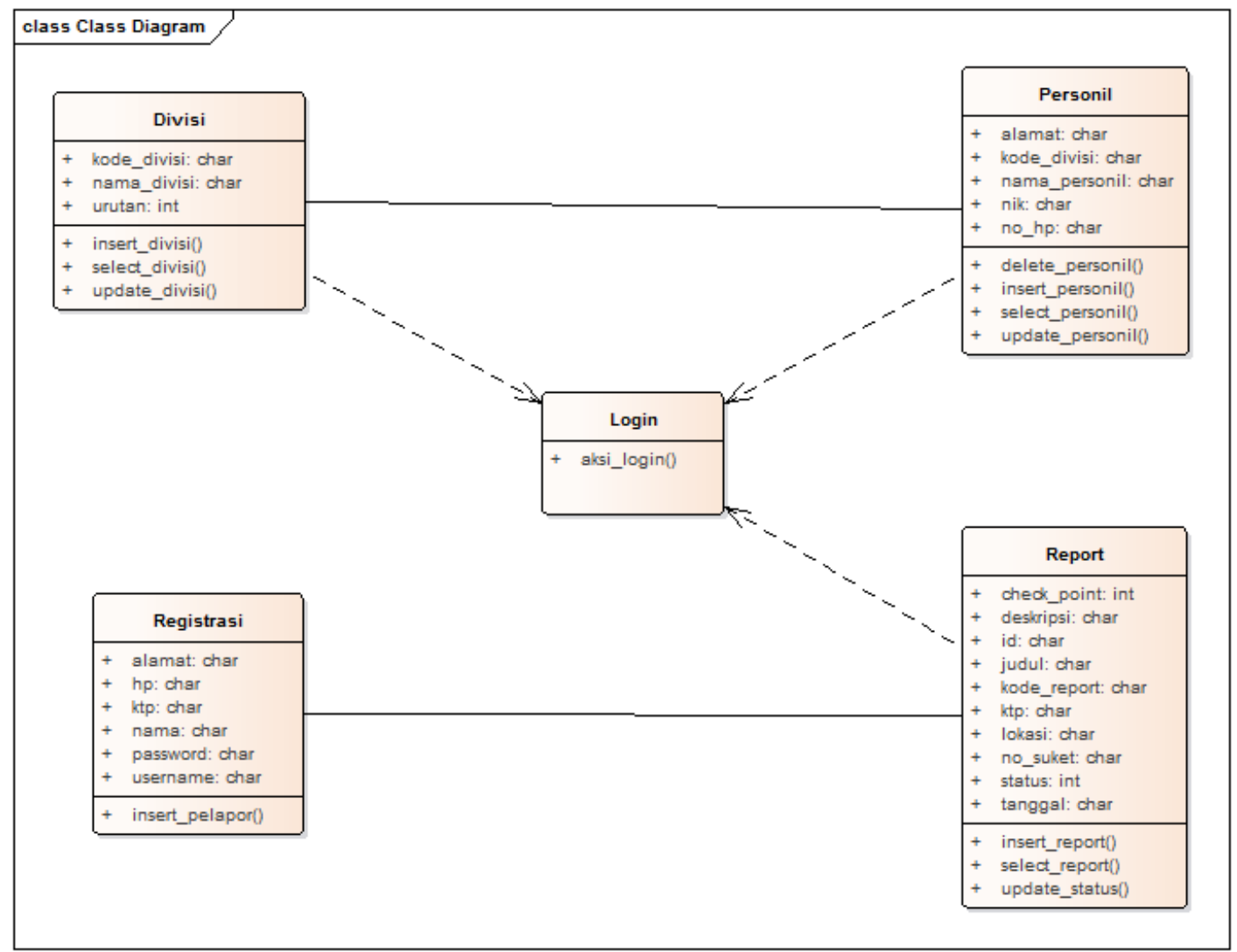

Gambar 6. Class Diagram

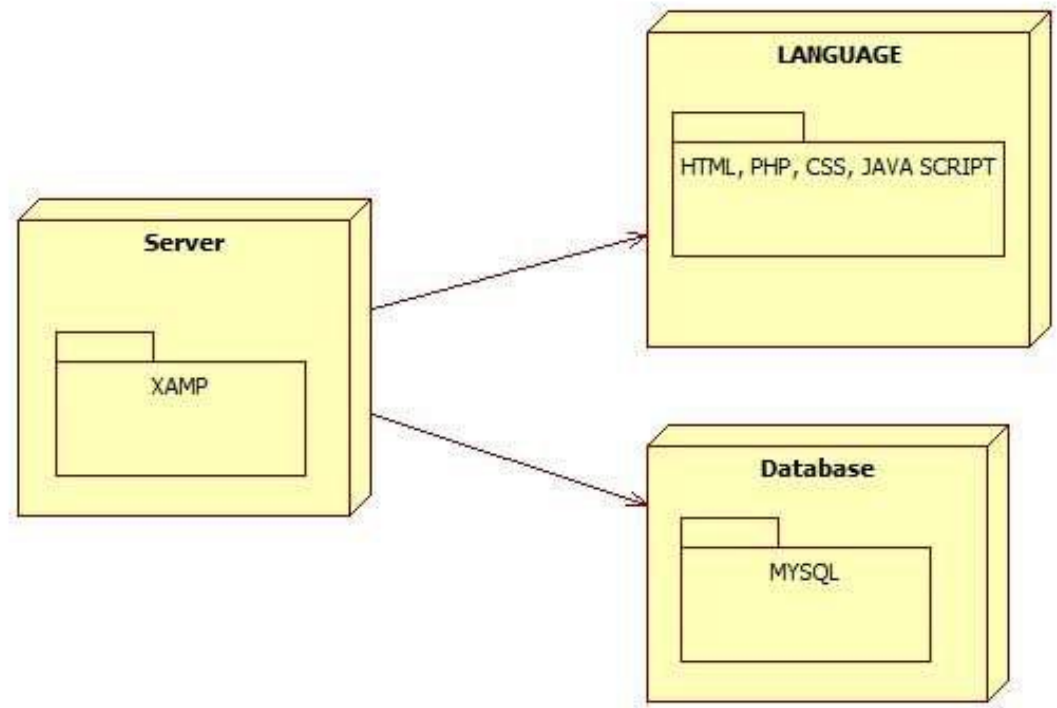

Gambar 7. Deployment Diagram 
Username administrator

Password

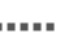

Pelapor Umum

Personil

Super Admin

\section{Sign In}

Gambar 8. Halaman Login

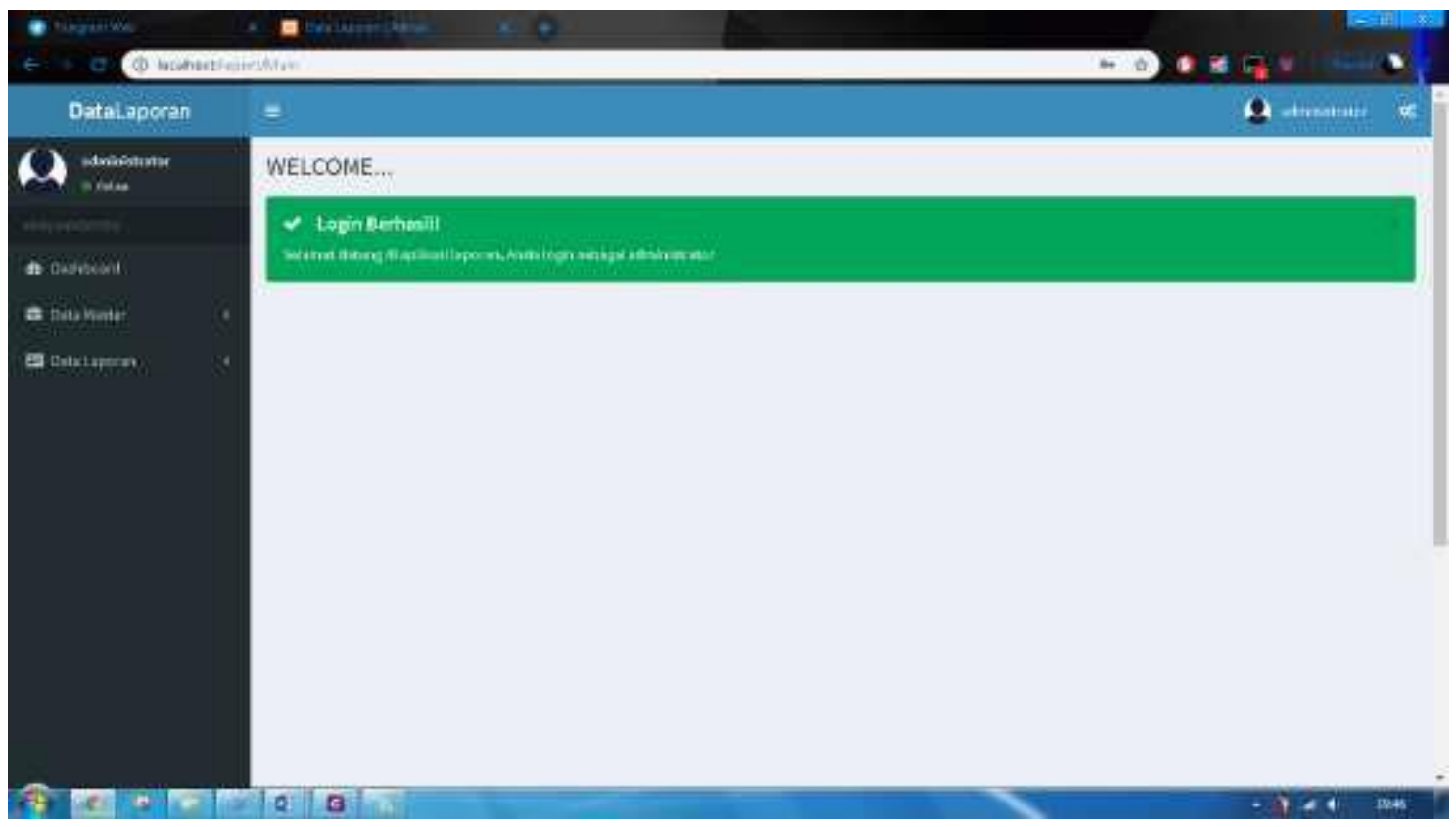

Gambar 9. Halaman Utama 


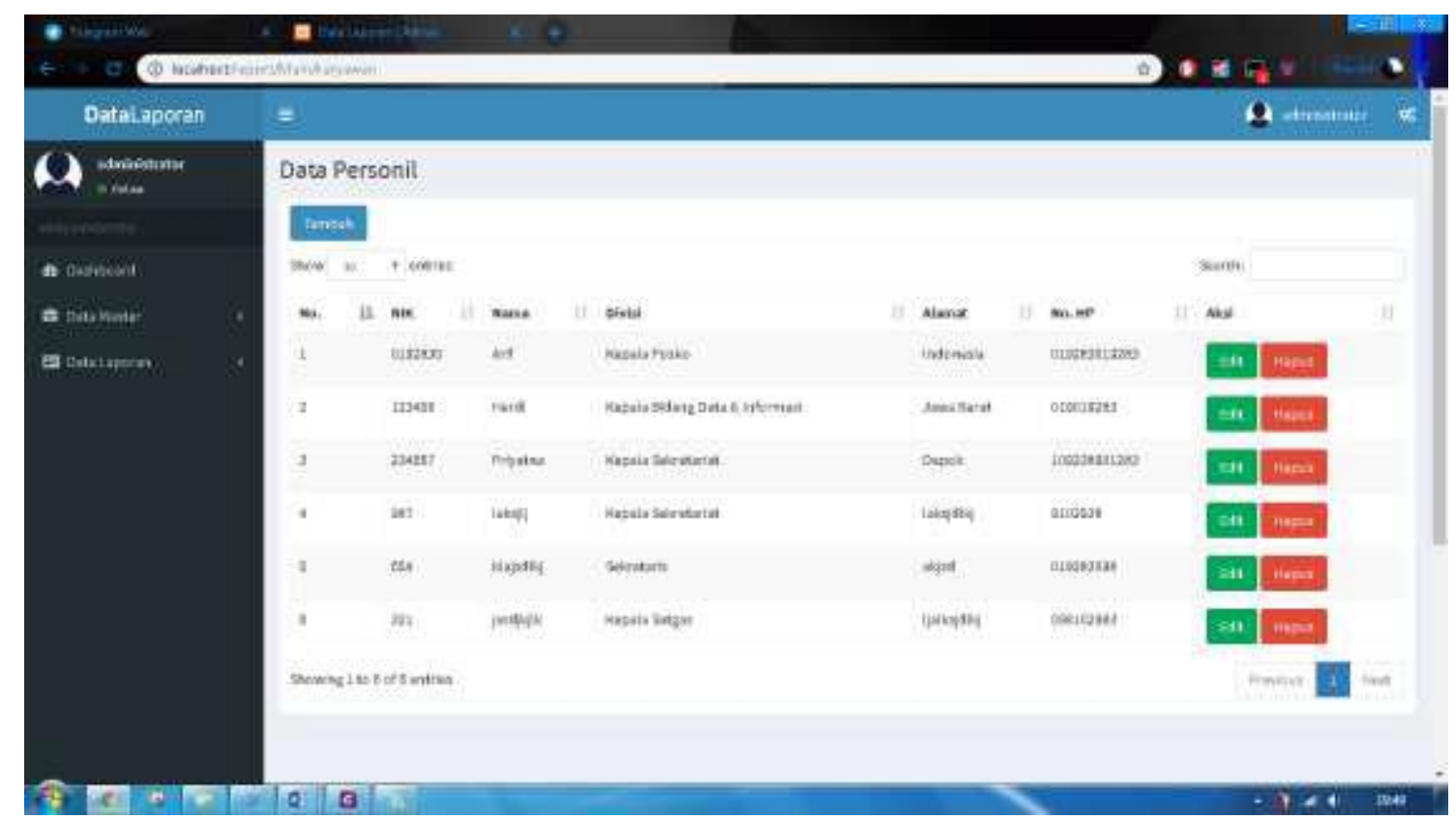

Gambar 10. Halaman Data Personil

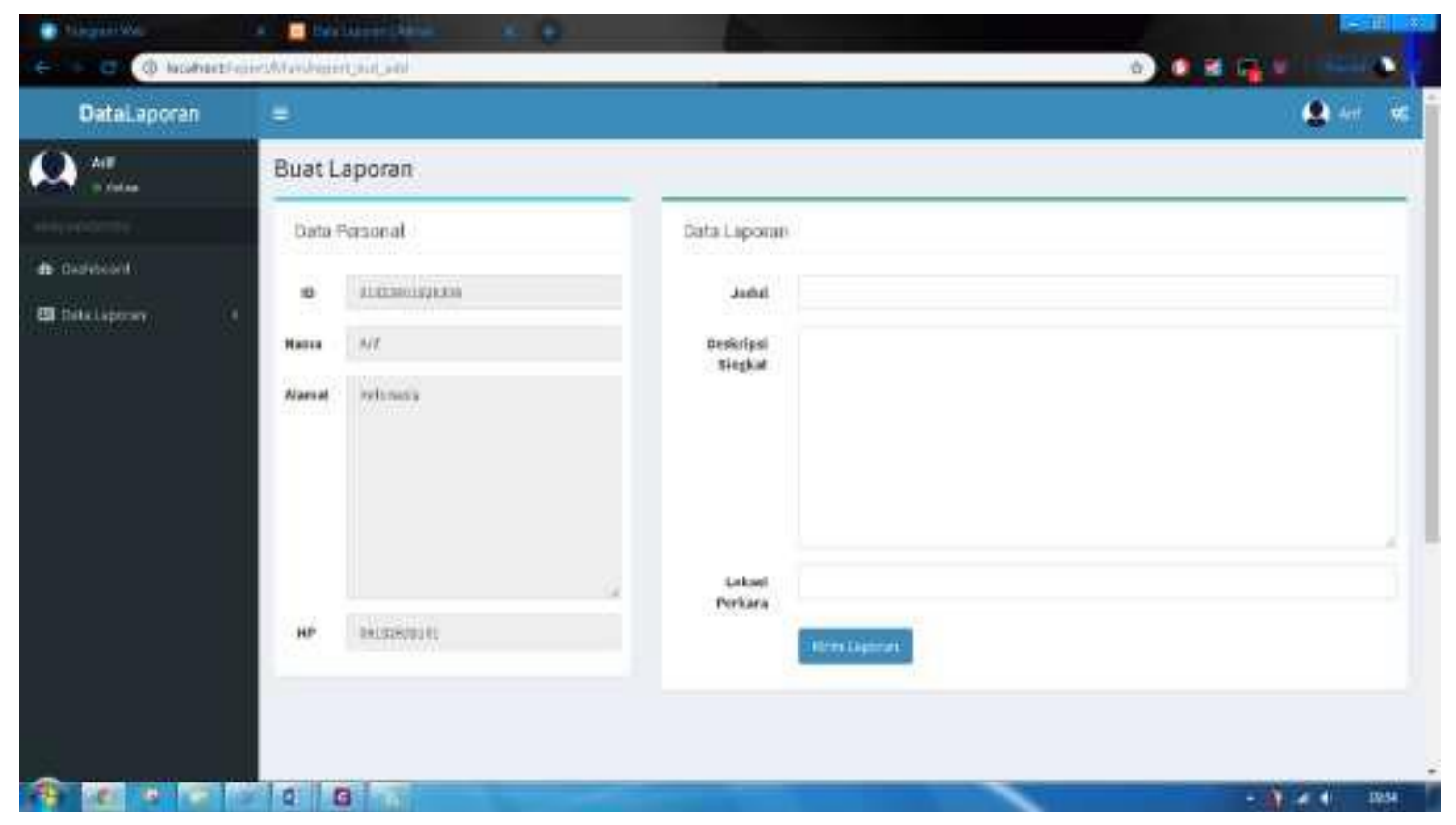

Gambar 11. Halaman Pembuat Laporan 


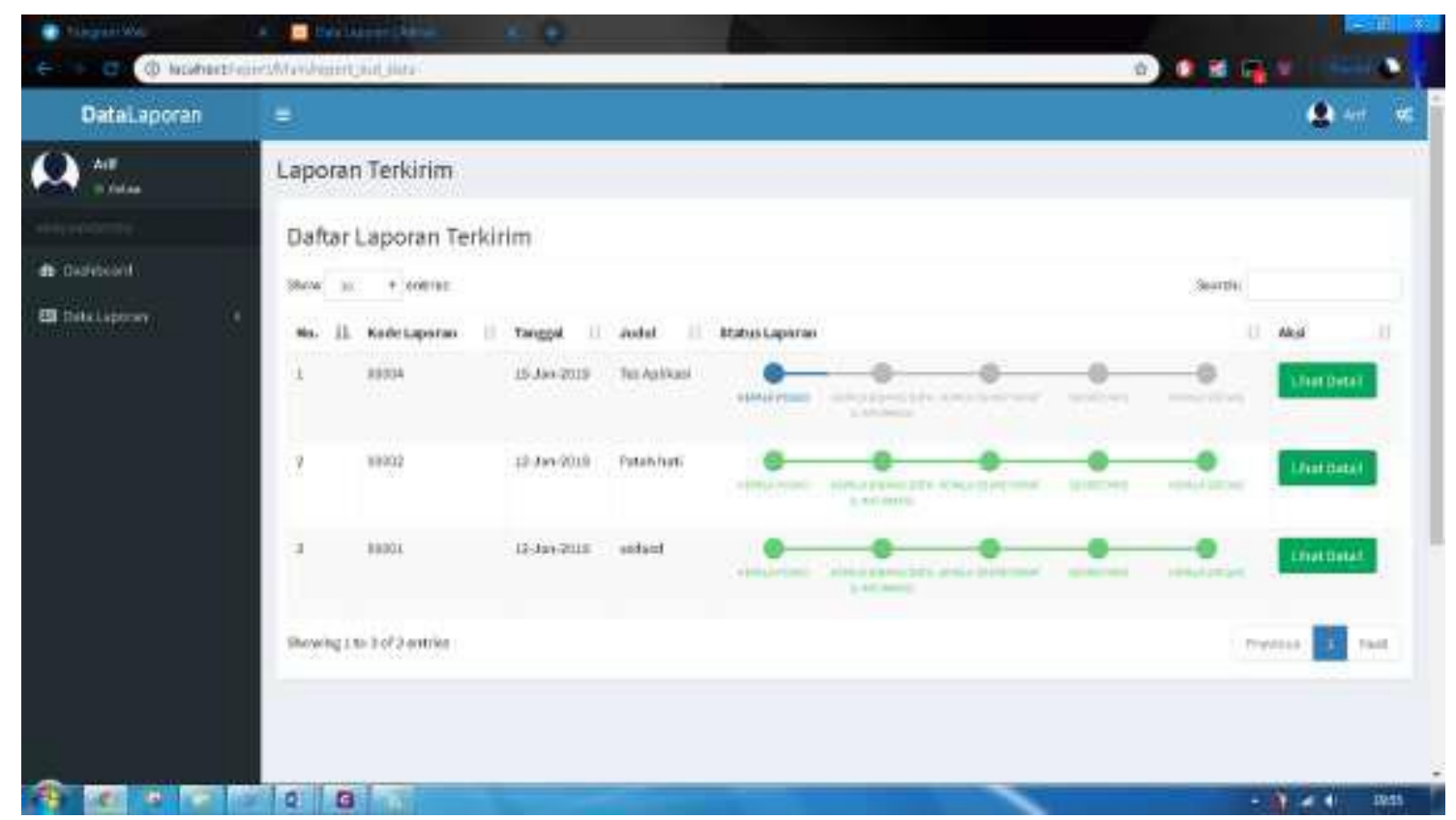

Gambar 12. Halaman List Laporan

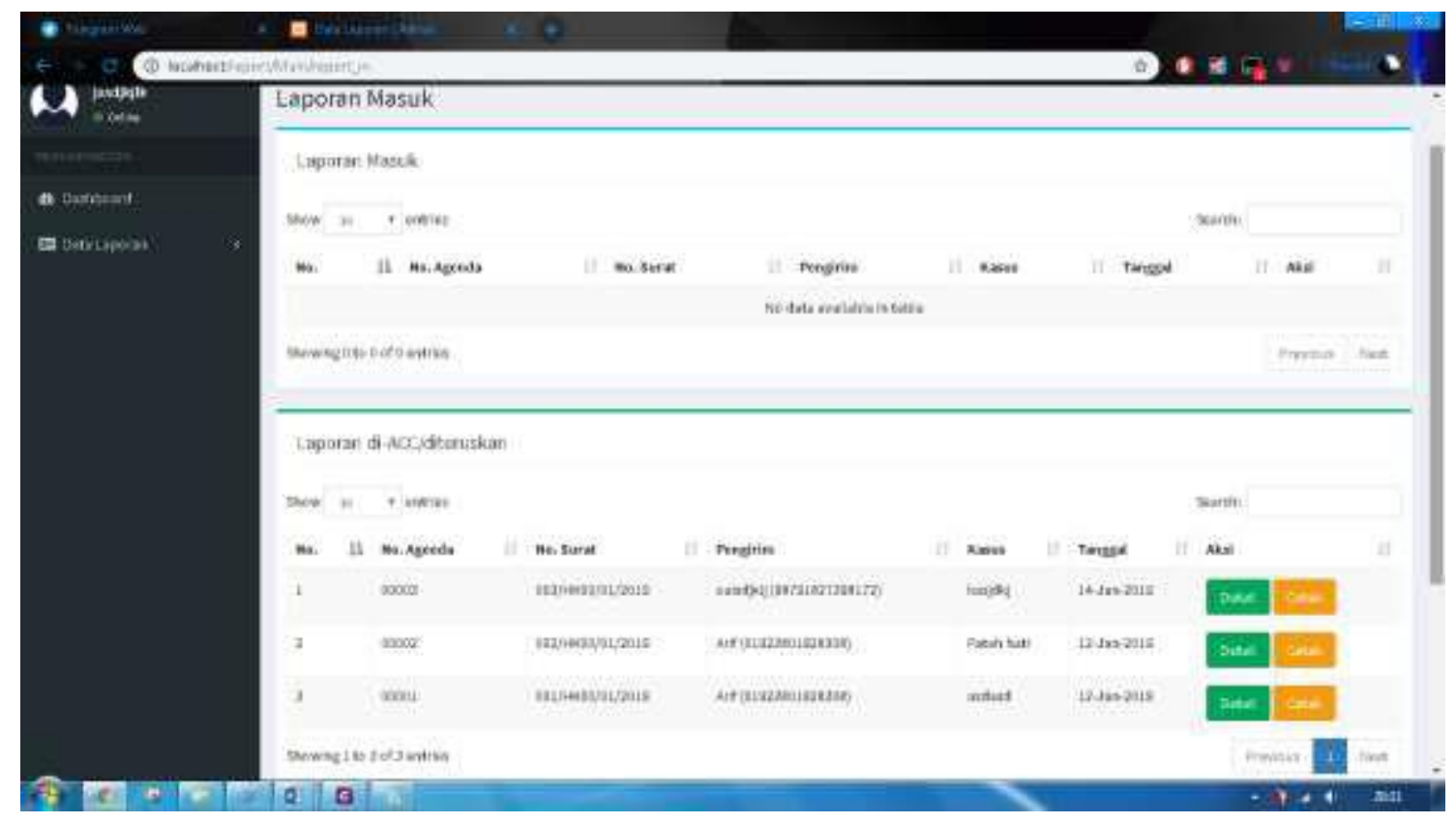

Gambar 13. Halaman Utama Kaposko 


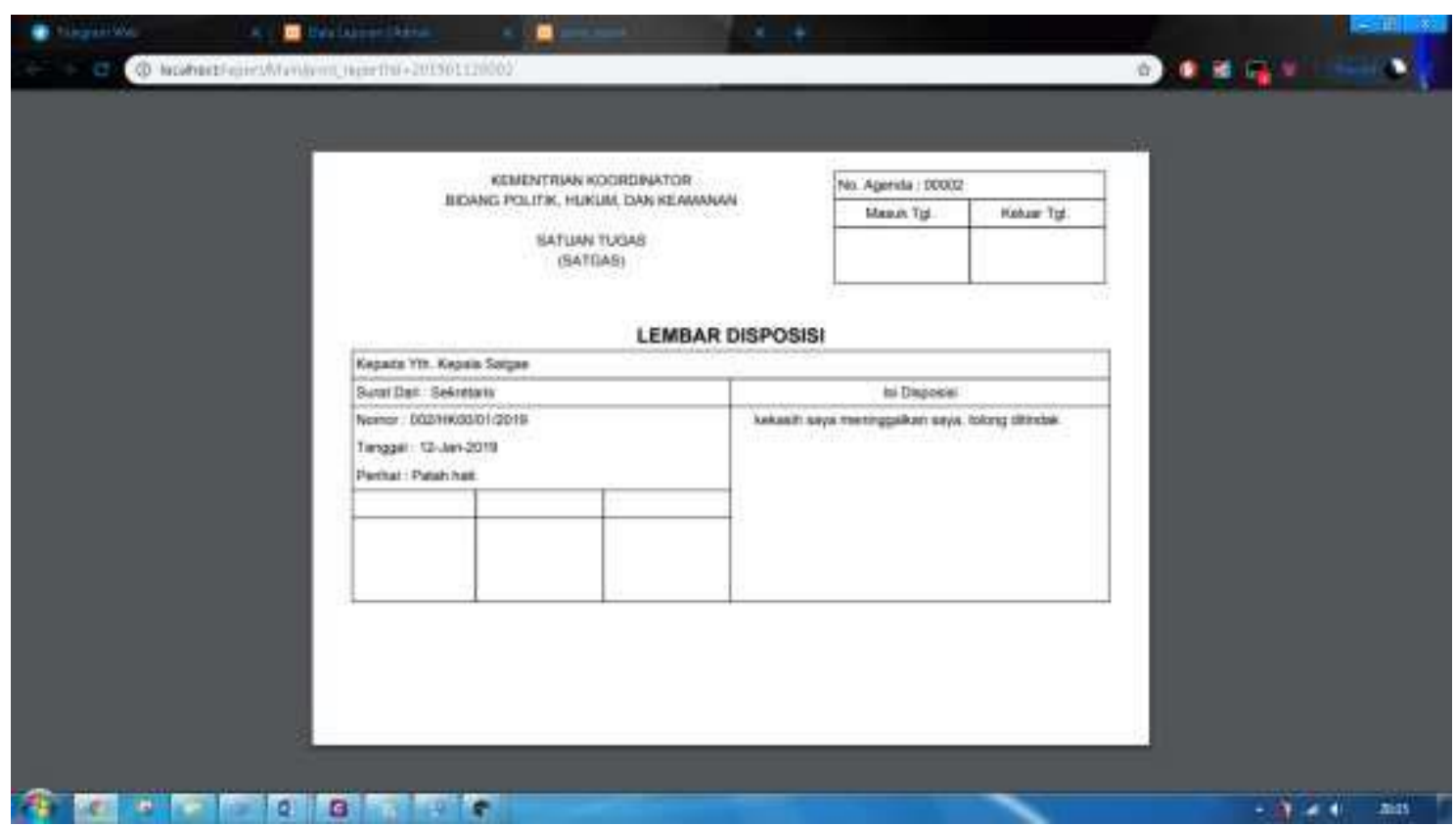

Gambar 14. Halaman Cetak Lembar Disposisi

\section{KESIMPULAN DAN REKOMENDASI}

Dari proses analisis, perancangan dan implementasi yang dilakukan diambil kesimpulan sebagai berikut :

Telah dikembangkan Sistem Informasi Manajemen Pendataan Laporan berbasis web pada posko Satgas Saber Pungli. Sistem suratmenyurat berbasis web pada posko Satgas Saber Pungli dapat memberikan solusi terhadap permasalah yang dihadapi dalam pengolahan data transaksi sehingga lebih akurat dan efisien.

Telah dilakukan pengujian sistem pada posko Satgas Saber Pungli sehingga sistem dapat berjalan sesuai dengan yang diharapkan.

Untuk pengembangan sistem selanjutnya, dapat diberikan rekomendasi sebagai berikut:
Obyek penelitian dapat mencakup masalah yang lebih luas yaitu tidak hanya mengacu pada sistem pelaporan saja melainkan dapat mengelompokkan laporan berdasarkan wilayah atau kriteria lain.

Aplikasi web dapat dikembangkan sesuai dengan perkembangan fungsi Satgas Saber Pungli agar lebih update sesuai dengan kebutuhan dikemudian hari.

\section{REFERENSI}

Alexander F. K. Sibero, 2011, Kitab Suci Web Programming, MediaKom, Yogyakarta Betha, Sidik. 2012. Pemrograman Web dengan $P H P$, Informatika, Bandung. 
Davis B. Gordon. 1985. Kerangka Dasar, Sistem

Informasi Manajemen, Seri manajemen No.

90-A, PT Pustaka Binaman Pressindo.

Kustiyaningsih. 2011. Pemograman basis data

berbasis WEB menggunakan PHP dan Mysql.

Yogyakarta : Penerbit Graha Ilmu.

Kusrini. 2007. Konsep dan Aplikasi Sistem

Pendukung Keputusan. Penerbit Andi,

Yogyakarta

Meliala, Adrianus, Komisioner Kompolnas

https://nasional.kompas.com/read/2018/07/20/1444

0551/satgas-saberpungli-dipandang-jadi-

pekerjaan-tambahan-polri.

Subhan, Mohamad. 2012. Analisa Perancangan

Sistem. Lentera Ilmu Cendekia.

Tata Sutabri. 2012. Analisis Sistem Informasi. Andi.

Yogyakarta.

Widodo, Prabowo Pudjo dan Herlawati, 2011.

Menggunakan UML (Unified Modeling

Language). Informatika Bandung.

Yakub. 2012. Pengantar Sistem Informasi,

Yogyakarta: Graha Ilmu.

Zakiyudin, Ais. 2012. Sistem Informasi Manajemen.

Jakarta: Mitra Wacana Media.

Jurnal Teknologi Informatika \& Komputer| Volume 3 No. 2, September 2017

http://journal.thamrin.ac.id/index.php/jtik/article/view/396/pdf 